\title{
Effects of Leukocyte Extract from the American Alligator (Alligator mississippiensis) on Antibiotic-Resistant Bacteria
}

\author{
Venkata Machha, Paige Spencer and Mark Merchant* \\ Department of Chemistry, McNeese State University, Lake Charles, LA 70609, USA
}

\begin{abstract}
Treatment of clinical isolates of human pathogenic bacteria, which were known to be resistant to multiple commonly-used antibiotics, with refined leukocyte extracts from the American alligator (Alligator mississippiensis) resulted in a time- and concentration-dependent inhibition of bacterial proliferation. The alligator leukocyte extract exhibited the strongest antibacterial effect on Pseudomonas aeruginosa followed by Enterococcus faecium and then Klebsiella pneumonia. The antibacterial activities were acid-soluble, heat-stable at $70^{\circ} \mathrm{C}$ for one h, sensitive to protease treatment, and did not require divalent metal ions for antibacterial activity. Collectively, these data strongly suggest that the molecule(s) responsible for the observed antibacterial activities are small, cationic antimicrobial peptides.
\end{abstract}

Keywords: Antibiotic resistance, antimicrobial peptides, crocodilians, innate immunity.

\section{INTRODUCTION}

The widespread use of antibiotics, both in human medicine and veterinarian use, has contributed to the growing problem of bacterial resistance to commonly used drugs [1]. Inappropriate use of antibiotics, by both health care professionals [2] and patients [3], has put selective pressure on bacteria to develop and transfer antibiotic resistance genes. In addition, high antibiotic usages in veterinary medicine [4] and agricultural practices [5] have exacerbated this problem. As a result, much time and effort is currently spent in search of new classes of antibiotics, particularly in the area of natural products [6].

Alligators are territorial animals that are prone to serious injuries as they engage in both intraspecies and interspecies aggression. Despite the fact that they live in environments rich in potentially pathogenic microorganisms, these injuries often heal without signs of infection. Results from previous studies in our laboratory have shown that the American alligator (A. mississippiensis) exhibits potent innate immunity against various species of bacteria [7], parasitic amoebae [8], and three enveloped viruses [9]. Mateo et al. [10] stated that eosinophils of healthy American alligators have phagocytic and microbial capacity against Staphylococcus aureus. Cuchens and Clem [11] first assessed the existence of two distinct functional B-and T-like populations of lymphocytes in the American alligator. Furthermore, studies in our laboratory have shown that challenging alligators with bacterial lipopolysaccharide results in a large increase in heterophils [12], and that refined alligator leukocyte extracts exhibit acid-soluble, heat-stable, broad spectrum antimicrobial activities [13]. Many peptide antibiotics have been isolated from leukocytes belonging to a broad spectrum of eukaryotic organisms [14]. The primary

*Address correspondence to this author at the Department of Chemistry, McNeese State University, Lake Charles, LA 70609, USA;

Tel: 337-475-773; Fax: 337-475-5950;

E-mail:mmerchant@mcneese.edu goal of this study was to investigate the effects of alligator leukocyte extracts on antibiotic-resistant pathogenic bacteria. The kinetic data presented in this study indicate that alligator leukocyte extracts display antibacterial activity against antibiotic-resistant pathogenic bacteria.

\section{MATERIALS AND METHODS}

\subsection{Bacterial Strains}

The following bacterial species, derived from human clinical isolates, were used for these studies: Pseudomonas aeruginosa, Enterococcus faecium, Klebsiella pneumoniae (13883). These three antibiotic-resistant bacterial strains were acquired from the Center from Disease Control, Atlanta, GA, USA).

\subsection{Treatment of Animals}

Juvenile alligators were housed in $3.25 \mathrm{~m} \times 3.25 \mathrm{~m}$ outdoor fenced pens each with a subterranean $364 \mathrm{~L}$ tank which furnished $1.00 \mathrm{~m}^{2}$ of water surface. Blood samples were drawn from the spinal vein $[15,16]$ using $3.8 \mathrm{~cm} 18$ ga. needles and $20 \mathrm{~mL}$ syringes, and transferred to $250 \mathrm{~mL}$ bottles containing $15 \mathrm{ml}$ of $0.5 \mathrm{M}$ EDTA. These bottles were immediately inverted to make sure that the EDTA was properly incorporated into the blood. All of the animal handling protocols used in this study were approved by the McNeese State University Animal Care and Use Committee.

\subsection{Isolation and Processing of Leukocytes}

The bottles filled with whole blood were left undisturbed for $2 \mathrm{~h}$. The erythrocytes began to settle and the whole blood was separated into three layers. The top layer, containing leukocytes, was removed using transfer pipettes and the same process was repeated every $1 \mathrm{hr}$. The leukocytes were collected by centrifugation at $800 \mathrm{xg}\left(25^{\circ} \mathrm{C}\right)$ for $20 \mathrm{~min}$. The cell pellet was gently resuspended in normal saline and again centrifuged at $800 \times \mathrm{xg}\left(25^{\circ} \mathrm{C}\right)$ for $5 \mathrm{~min}$. The leukocyte pellet was resuspended in one volume of $10 \%$ acetic acid (v/v) and later vortexed for $5 \mathrm{~min}$. The leukocytes were disrupted using 20 strokes of a Dounce homogenizer. Then the 
homogenate was centrifuged at 20,000xg for $30 \mathrm{~min}$. The clear supernatant was exchanged to $0.1 \%$ acetic acid by using $1 \mathrm{kDa}$ microcentrifugal concentrators (Pall Corporation, East Hills, NY) and stored at $5^{\circ} \mathrm{C}$.

\subsection{Antibacterial Assay}

The antibacterial assay was conducted spectrophotometrically $\left(\mathrm{OD}_{600}\right)$ to measure microbial growth. Twenty $\mu \mathrm{L}$ of each $\log$ phase bacterial culture were pipetted into four wells of a 96 well microtiter plate of respective division. $750 \mu \mathrm{L}$ aliquots of sterile nutrient broth were pipetted into each well. Then $75 \mu \mathrm{L}(200 \mu \mathrm{g}$ ALE

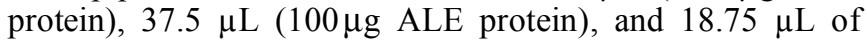
leukocyte extract ( $50 \mu \mathrm{g}$ ALE protein) were pipetted into the respective wells. For the negative solvent control, $75 \mu \mathrm{L}$ of $0.1 \%$ acetic acid were used. The initial bacterial growth was measured spectrophotometrically $\left(\mathrm{OD}_{610}\right)$ [17] by using a Benchmark Plus ${ }^{\mathrm{TM}}$ microtiter plate spectrometer (Bio-Rad Laboratories, Hercules, CA). Then the microtiter plate was allowed to incubate at $37^{\circ} \mathrm{C}$ for $48 \mathrm{~h}$. During the incubation, the optical densities of the cultures were measured $(610 \mathrm{~nm})$ at $3,6,12,24,36$, and $48 \mathrm{~h}$ after inoculation.

\subsection{Statistics and Controls}

The results displayed represent the means \pm standard deviations of eight independent determinations. The statistical significance between treatment groups was determined by subjection of the data to analysis of variance using Duncan's post-hoc comparisons.

\section{RESULTS}

Alligator leukocyte extract was effective as an antibacterial agent against the three bacterial species tested. The bacterial cultures were treated with 5,10 , or $20 \mu \mathrm{g}$ ALE protein $/ \mathrm{mL}$ of culture. The solvent control $(0.1 \%$ acetic acid $)$ did not exhibit growth inhibition for any bacterial strains tested. The kinetics of antibacterial activity of the alligator leukocyte extracts are displayed in Fig. (1-3).

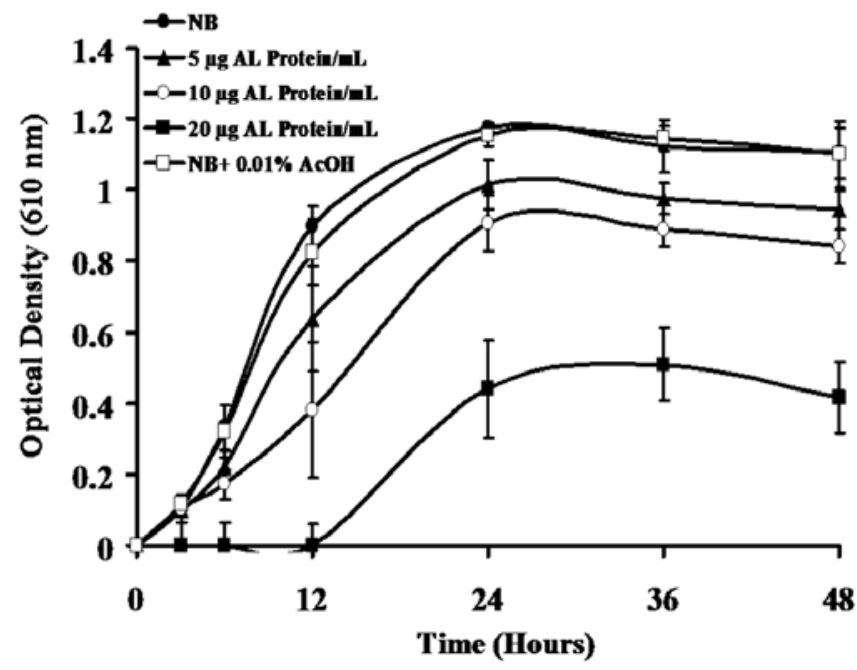

Fig. (1). Kinetic analysis of the antibacterial activity of alligator leukocyte extract. The concentration-dependent effects of alligator leukocyte on Pseudomonas aeruginosa strain growth inhibition were examined. The results are represented as optical density at 610 $\mathrm{nm}$ and expressed as the means \pm standard deviations for three independent determinations. $\mathrm{NB}=$ nutrient broth.

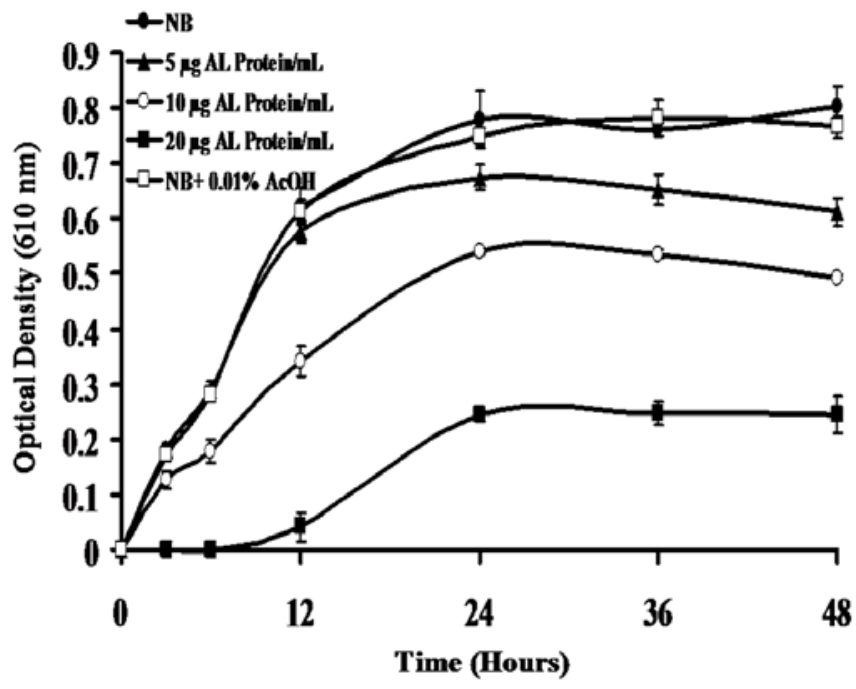

Fig. (2). Kinetic analysis of the antibacterial activity of alligator leukocyte extract. The concentration-dependent effects of alligator leukocyte on Klebsiella pneumonia strain growth inhibition were examined. The results are represented as optical density at $610 \mathrm{~nm}$ and expressed as the means \pm standard deviations for three independent determinations. $\mathrm{NB}=$ nutrient broth.

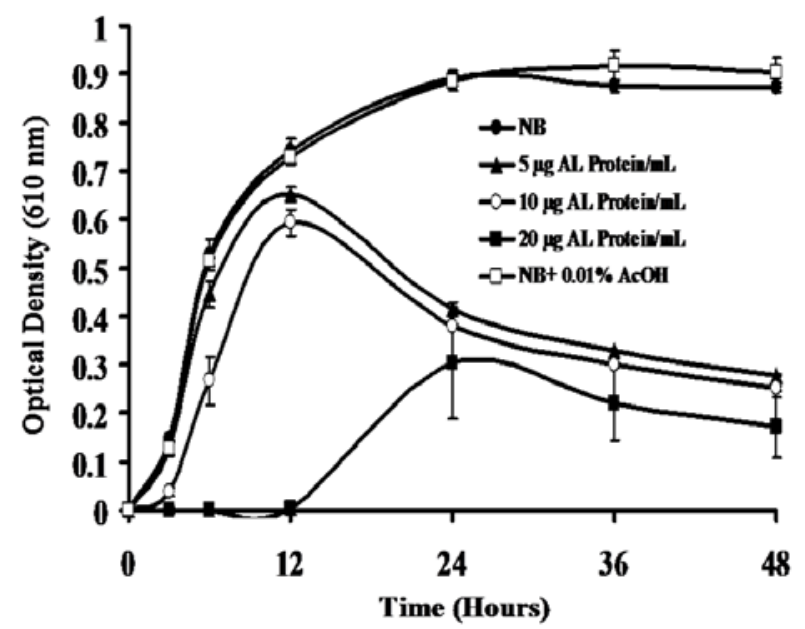

Fig. (3). Kinetic analysis of the antibacterial activity of alligator leukocyte extract. The concentration-dependent effects of alligator leukocyte on Enterococcus faecium strain growth inhibition were examined. The results are represented as optical density at $610 \mathrm{~nm}$ and expressed as the means \pm standard deviations for three independent determinations. $\mathrm{NB}=$ nutrient broth.

Fig. (1) shows the kinetics of the antibacterial activities of alligator leukocyte extract against Pseudomonas aeruginosa. A small, but significant, decrease in the maximum growth was observed with $5 \mu \mathrm{g} / \mathrm{mL}$ ALE protein as early as 6 hours after inoculation $(\mathrm{p}<0.05)$, relative to control Pseudomonas cultures. This concentration exhibited strong antibacterial actions at later time points (12-24 hours). Treatment of multidrug-resistant Pseudomonas aeruginosa cultures with $10 \mu \mathrm{g} / \mathrm{mL}$ ALE protein resulted in substantial antibacterial activity as early as 3 hours $(\mathrm{p}<0.05)$, and continued to show moderate activity for the duration of the 48 hour study. The concentration of $20 \mu \mathrm{g} / \mathrm{mL}$ ALE protein was found to be strongly growth inhibiting for Pseudomonas aeruginosa, as it exhibited complete growth inhibition up to 
12 hours, and bacterial growth was not observed until 24 hours in the presence of this higher concentration. The highest concentration of ALE protein tested inhibited Pseudomonas aeruginosa growth approximately 60-65\% (p $<0.01$ ) from 24 to 48 hours after inoculation (Fig. 1). On the other hand, no inhibition was found in the presence of nutrient broth and the $0.1 \%$ acetic acid (v/v) negative control $(\mathrm{p}>0.05)$.

The data in Fig. (2) illustrate the kinetics of the antibacterial activities of alligator leukocyte extract against Klebsiella pneumonia. Increasing concentrations (5-20 $\mu \mathrm{g} / \mathrm{mL}$ ) of alligator leukocyte extract added to the cultures produced a concentration-dependent decrease in bacterial growth. Treatment of the cultures with $5 \mu \mathrm{g} / \mathrm{mL}$ ALE protein resulted in small increments of growth inhibition at 24 hours ( $16 \%$ inhibition, $\mathrm{p}<0.05$ ), and continued through 48 hours ( $22 \%$ inhibition, $\mathrm{p}<0.05$ ). The concentration of $10 \mu \mathrm{g} / \mathrm{mL}$ ALE protein produced a small, but significant ( $\mathrm{p}<0.05)$, growth inhibitory effect as early as 3 hours after inoculation of the Klebsiella cultures. This activity was observed to be much stronger at later time points in the study and culminated in a $30 \%$ inhibition of bacterial growth at 48 hours. The initial bacterial growth was completely inhibited up to $6 \mathrm{~h}$ incubation by the $20 \mu \mathrm{g} / \mathrm{mL}$ ALE protein ( $\mathrm{p}<$ 0.05 ), and continued to exhibit strong antibacterial growth activity throughout the $48 \mathrm{~h}$ study. No significant bacterial growth inhibitory effect of nutrient broth and solvent control $(0.1 \%$ acetic acid) was observed $(\mathrm{p}>0.05)$.

The results displayed in Fig. (3) reveal the kinetics of the antibacterial activities of alligator leukocyte extract against Enterococcus faecium. The addition of ALE protein to the cultures resulted concentration-dependent growth inhibition of Enterococcus faecium. The Enterococcus faecium treated with $20 \mu \mathrm{g} / \mathrm{mL}$ leukocyte extract did not show measurable bacterial growth until $12 \mathrm{~h}$ after inoculation, which was similar to that observed with Pseudomonas aeruginosa. However, unlike the Pseudomonas aeruginosa and Klebsiella pneumonia cultures treated with 5 and $10 \mu \mathrm{g} / \mathrm{mL}$ leukocyte extract, the Enterococcus faecium exhibited greater growth inhibition after the $12 \mathrm{~h}$ incubation period. The solvent control, $0.1 \%$ acetic acid (v/v), and nutrient broth alone had no inhibition effect on bacterial growth at any time point observed ( $\mathrm{p}>0.05)$.

The results displayed in Table 1 show the effects of mild heat $\left(56^{\circ} \mathrm{C}, 30 \mathrm{~min}\right)$, protease, and EDTA-treatment on the antibacterial effects of ALE against the Pseudomonas aeruginosa multidrug resistant clinical isolate. These data were collected using the antimicrobial zone of inhibition assay. Incubation of $\mathrm{ALE}$ at $70^{\circ} \mathrm{C}$ for one $\mathrm{h}$, prior to addition the bacterial culture, resulted in no significant change in antibacterial activity $(\mathrm{p}>0.05)$. In addition, treatment with 20 $\mathrm{mM}$ EDTA also resulted in no substantial changes in antibacterial action ( $p>0.05)$. However, treatment of the ALE with $10 \mathrm{U}$ of pronase, a protease isolated from $S$. griseus, for $30 \mathrm{~min}$ at $37^{\circ} \mathrm{C}$ resulted in a $97.7 \%$ decrease in antibacterial activity $(\mathrm{p}<0.01)$.

\section{DISCUSSION}

Antibacterial peptides are vital components of the innate immune system that protect hosts from different types of pathogenic bacteria. Most antibacterial peptides exhibit cationic and amphipathic properties [18]. Because of these chemical characteristics, they have electrostatic interaction with the negatively charged head groups of lipids in the cytoplasmic membrane, are able to insert into the membrane, and cause channel formation leading to leakage of essential nutrients from the cell [19]. Antibiotic peptides are expressed in tissues exposed to microbes such as mucosal surfaces, skin, and in cytoplasmic granules of professional phagocytes [20].

Table 1. Alligator Acid Soluble Leukocyte Extracts were Treated with Protease, Heat, or EDTA to Observe the Effects on Antibacterial Activity Against the Multidrug Resistant Pseudomonas aeruginosa Clinical Isolate

\begin{tabular}{|c|c|}
\hline Extract Treatment & Antimicrobial activity \\
\hline \hline None & $100.0 \pm 2.2$ \\
\hline Pronase $\left(10 \mathrm{U}, 30 \mathrm{~min}, 37^{\circ} \mathrm{C}\right)$ & $2.3 \pm 0.8$ \\
\hline $70^{\circ} \mathrm{C}, 1 \mathrm{hr}$ & $97.4 \pm 3.9$ \\
\hline $50 \mathrm{mM}$ EDTA & $98.6 \pm 2.9$ \\
\hline
\end{tabular}

The results represent the means \pm standard deviations for eight independent determinations.

In addition to the generation of toxic oxygen radicals and nitric oxide, leukocytes produce a variety of antibacterial peptides. These peptides were first reported as crude extracts from leukocytes and were shown to possess antimicrobial activity in vitro [21]. Zeya and Spitznagel [22] have established that rabbit and guinea pig granulocytes contain a family of low molecular weight lysosomal cationic proteins with selective antibacterial activity.

Alligator leukocyte extracts exhibited antibacterial activities against all three bacterial species such as Pseudomonas aeruginosa, Klebsiella pneumonia, and Enterococcus faecium, which are pathogenic to humans (Figs. 1, 2, and 3). All three bacterial strains tested in this study had developed resistance to chemically modified and synthesized antibiotics. The Pseudomonas aeruginosa clinical isolate had developed resistance (Table 2) to aminoglycosides (gentamicin, tobramycin, amikacin), quinolones (ciprofloxacin), and $\beta$-lactams (imipenem, ceftazimide) [23]. The Enterococcus faecium isolate showed resistance to $\beta$ lactams (ampicillin), and glycopeptides (vancomycin) [24]. The Klebsiella pneumonia isolate was resistant (Table 2) to aminoglycosides (tobramycin), and quinolones (ciprofloxacin) [25]. The aminoglycosides inhibit protein synthesis by binding to the $30 \mathrm{~S}$ subunit of the ribosome [26]. The $\beta$ lactams inhibit the peptidoglycan-assembling transpeptidases located on the outer face of the cytoplasmic membrane [27]. Quinolones bind to subunit A of DNA gyrase, which maintains the ordered structure of the chromosome inside the cells [23]. The amphipathicity of the antimicrobial peptides allows binding and disruption of the integrity of the bacterial cell wall by generating pores in the cell wall [28]. The pores cause leakage of cellular contents, and the differences in osmolalities across the outer membranes cause the cells to lyse. Since the peptides are targeted at the bacterial cell wall structure, it is rather difficult for bacteria to become resistant 
Table 2. Antibiotic Resistance Properties of the Clinical Isolate Bacteria. The Bacterial Strains were Derived from Human Clinical Isolates that were Resistant to a Broad Spectrum of Commonly Used Antibiotics

\begin{tabular}{|c|c|c|}
\hline Bacterial Strains & $\begin{array}{c}\text { Resistant } \\
(\mathrm{MIC}>16 \mu \mathrm{g} / \mathrm{mL})\end{array}$ & $\begin{array}{c}\text { Intermediate Resistance } \\
(4 \mu \mathrm{g} / \mathrm{mL}<\mathrm{MIC} \leq 16 \mu \mathrm{g} / \mathrm{mL})\end{array}$ \\
\hline Pseudomonas aeruginosa & $\begin{array}{c}\text { Aztreonam } \\
\text { Cefepime } \\
\text { Cefotaxime Ceftazidime } \\
\text { Ceftriaxone } \\
\text { Ciprofloxacin } \\
\text { Gentamycin Imipenam Levofloxacin Meropenem } \\
\text { Pipercillin } \\
\text { Tobramycin }\end{array}$ & $\begin{array}{c}\text { Amikacin } \\
\text { Cefepime } \\
\text { Ceftazidime }\end{array}$ \\
\hline Enterococcus faecium & $\begin{array}{c}\text { Ampicillin } \\
\text { Chloramphenicol Doxycycline } \\
\text { Gentamycin Levofloxacin Penecillin } \\
\text { Rifampicin Vancomycin }\end{array}$ & $\begin{array}{l}\text { Chloramphenicol } \\
\text { Linezolid }\end{array}$ \\
\hline Klebsiella pneumoniae & $\begin{array}{c}\text { Amikacin Amoxicillin } \\
\text { Ampicillin } \\
\text { Cefazolan } \\
\text { Cefotetan } \\
\text { Cefoxitin } \\
\text { Ceftazidime } \\
\text { Chloramphenicol Ciprofloxacin Levofloxacin } \\
\text { Trimethoprim }\end{array}$ & $\begin{array}{l}\text { Cefotaxime } \\
\text { Ceftriaxone } \\
\text { Tobramycin }\end{array}$ \\
\hline
\end{tabular}

$\mathrm{MIC}=$ minimal inhibitory concentration .

to such peptides, and the generation of resistant mutants would require alterations in membrane composition [18].

The kinetic studies displayed in Figs. (1-3) show that inclusion of 5,10 , and $20 \mu \mathrm{g} / \mathrm{mL}$ of ALE protein inhibited the multidrug resistant bacterial growth in a time- and concentration dependent fashion. The results from previous studies in our laboratory suggested that alligator leukocyte peptides express protease-sensitive, heat-stable, and acidsoluble antimicrobial activities [7]. The results tabulated in Table 1 show similar properties for the anti- Pseudomonas aeruginosa properties of the ALE. The sensitivity of the antibacterial activity of the ALE to pronase indicates that the activity is due to the presence of a proteinaceous substance. The fact that the activity is not inhibited by EDTA suggests that the activity is not due to the presence of serum complement proteins, which have been shown to be sensitive to chelators of divalent metal ions [29]. The heat stability and acid solubility of the antibacterial activity suggests that the protein(s) responsible for the antibacterial effects of the ALE are small, cationic proteins.

\section{CONCLUSION}

All of these activities, and the data presented in this study indicate that cationic peptides are responsible for the antibacterial activity of alligator leukocyte extracts. Based on these studies alligator leukocyte peptides might be useful as a new class of antibiotic peptides in the clinical settings and for veterinary purposes.

\section{ACKNOWLEDGEMENTS}

The authors wish to thank the Centers for Disease Control for providing the antibiotic-resistant bacterial clinical isolates. This research was supported by a LEQSF (Louisiana Education Quality Science Fund) grant awarded to M. Merchant, and by the National Oceanic and Atmospheric Administration (NA08NOS4630474).

\section{REFERENCES}

[1] Goossens H, Ferech M, Vander Stichele R, Elseviers M, ESAC project. Outpatient antibiotic use in Europe and association with resistance: a cross-national database study. Lancet 2005; 365: 57987.

[2] Bauchner H, Philipp B. Reducing Inappropriate Oral Antibiotic Use: A prescription for change. Pediatrics 1998; 102: 142-144

[3] Bauchner H, Pelton SI, Klein JO. Parents, physicians, and antibiotic use. Pediatrics 1999; 103: 395-401.

[4] Levy SB. Multidrug resistance - a sign of the times. N Engl J Med 1998; 338: 1376-1378.

[5] Khachatourians, GG. Agricultural use of antibiotics and the evolution and transfer of antibiotic-resistant bacteria. Can Med Assoc J 159: 1129-1136.

[6] Koehn FE, Carter GT. The evolving role of natural products in drug discovery. Nat Rev Drug Discov 2005; 4: 2006-2020.

[7] Merchant M, Roche C, Elsey RM, Prudhomme J. Antibacterial properties of serum from the American alligator (Alligator mississippiensis). Comp Biochem Physiol B 2003; 136: 505-13. 
[8] Merchant M, Thibodeaux D, Loubster K. Amoebacidal effects of serum from the American alligator (Alligator mississippiensis). J Parasitol 2004; 90: 1480-1483.

[9] Merchant M, Pallansch M, Paulman PL, Wells J, Nalca A, Ptak R. Antiviral activity of serum from the American alligator (Alligator mississippiensis). Antivir Res 2005; 66: 5-38

[10] Mateo M, Roberts E, Enright F. Inflammation induced by subcutaneous turpentine inoculation of young American alligators (Alligator mississippiensis). Am J Vet Res 1984; 45: 1870-75.

[11] Cuchens MA, Clem LW. Phylogeny of lymphocyte heterogeneity. IV. Evidence for T-like and B-like cells in reptiles. Dev Comp Immunol 1979; 3:65-475.

[12] Merchant M, Mills K, Williams S, Kleckley F, Sims A, Elsey RM, Bushnell J. Effects of bacterial polysaccharide on peripheral leukocytes in the American alligator (Alligator mississippiensis). Vet Immunol Immunopathol 2006; 111: 315-20.

[13] Merchant M, Leger N, Jerkins E, et al. Broad spectrum antimicrobial activities of leukocyte extracts from the American alligator (Alligator mississippiensis). Vet Immunol Immunopathol B 2005; 110: 221-8.

[14] Yeaman M, Yount N. Mechanisms of antimicrobial peptide action and resistance. Pharmacol Rev 2003; 55: 27-55

[15] Oslen G, Hessler J, Faith R. Technics for the blood collection and intravascular infusion of reptiles. Lab Animal Sci 1977; 25: 783-6.

[16] Zippel KC, Lillywhite HB, Mladnich CR. Anatomy of the crocodilian spinal vein. J Morphol 2003; 258: 327-35.

[17] Breuil C, Shindler DB, Sijher JS, Kushner DJ. Stimulation of lipase production during bacterial growth on alkanes. J Bacteriol 1978; 133: 601-6.

[18] Hancock R, Chapple DS. Peptide Antibiotics. Antimicrob Agent Chemother 1999; 43: 1317-23.
[19] van't Hof W, Veerman ECI., Helmerhorst EJ. Antimicrobial peptides: Properties and applicability. Biol Chem 2001; 382: 597619.

[20] Ganz T, Lehrer RI. Antibiotic peptides from higher eukaryotes: biology and applications. Mol Med Today 1999; 5: 292-7.

[21] Hirsch JG. Antimicrobial factors in tissues and phagocytic cells. Bacteriol Rev 1956; 24: 133-40.

[22] Zeay HI, Spitznagel JK. Arginine-rich proteins of polymorphonuclear leukocyte lysosomes. Antibacterial specificity and biochemical heterogeneity. J Exp Med 1968; 127: 927-41.

[23] Lambert PA. Mechanisms of antibiotic resistance in pseudomonas aeruginosa. J R Soc Med 2002; 41: 22-26.

[24] Landman D, Mobarakai NK, Quale JM. Novel antibiotic regimens against Enterococcus faecium resistant to ampicillin, vancomycin, and gentamycin. Antimicrob Agent Chemother 1993; 37: 19041908.

[25] Anderl JN, Franklin MJ, Stewart PS. Role of Antibiotic Penetration Limitation in Klebsiella pneumonia biofilm resistance to ampicillin and ciprofloxacin. Antimicrob Agents Chemother 2000; 44: 1818 24.

[26] Buss WC, Pratt MK, Robert K. Inhibition of mammalian microsomal protein synthesis by aminoglycoside antibiotics. J Antimicrob Chemother 1984; 14, 231-41.

[27] Guinard B, Entrenza JM, Moreillon P. $\beta$-lactams against methicillin-resistant Staphylococcus aureus. Curr Opin Pharmacol 2005; $5:$ 479-489.

[28] Ganz T. The role of antimicrobial peptides in innate immunity. Integr Comp Biol 2003; 43: 300-4.

[29] Merchant M, Verret B, Elsey RM. Divalent metal requirements for serum complement activity in the American alligator (Alligator mississippiensis). Comp Biochem Physiol B. 2005; 141: 289-93.

Received: March 18, 2011

(C) Machha et al.; Licensee Bentham Open.

This is an open access article licensed under the terms of the Creative Commons Attribution Non-Commercial License (http://creativecommons.org/licenses/by-nc/3.0/) which permits unrestricted, non-commercial use, distribution and reproduction in any medium, provided the work is properly cited. 